\title{
13. A Picture: From the Past and without a Past
}

Conversations 4:1 (2003), pp. 18-29.

At Boort Primary School Number 1796 in northern Victoria, we lined up four times a day: morning, midday and after the two playtimes. Except on Monday mornings, when boys saluted the flag and we all mumbled a pledge to cheerfully obey parents, teachers and the law, there was no ceremony. Called to attention, we turned right, and marched in pairs into school. Through the double doors, we stepped (no tramping) along the wooden-floored corridor, past the racks hung with hats, dangling leather school bags, a couple of hessian bags with scrap material shoulder straps, and one forgotten cardigan. We entered by grade. The little kids, infants to grade two, turned into the first room on the left, grades three and four into the next room, and grades five and six turned right into the room opposite. With just seventy or so in the primary school when I started in 1943, we had twenty to thirty children in each of the three classrooms.

Through my six years all three teachers were women. It was Miss Chalmers who finally seized me and, holding me tightly by the right wrist, forced me to bowl with an extended, straight arm. She saved me embarrassment, but I never learnt to bowl with the speed or spin to threaten any but the most incompetent of batsmen.

All rooms were austerely furnished with green-topped double desks with seats attached. The desks increased in size from row to row and room to room, and the desks' two enamel ink wells were inserted and filled when we made the momentous change from pencils to pens. Each room had a fire place, the wood fire lit on winter mornings; the teacher had a small table and chair, centrally placed for surveillance; and on one wall of each room were blackboards, and another window. We all sat so that the light of the windows came from the left as we faced the blackboard. Left-handers would have been writing in the shadow of their own hands and arms, but left-handers were compelled to labour with an awkward right hand, and to direct all vertical strokes, thick on the way down, fine on the way up, to slope to the right. Girl monitors were responsible for dusting and flowers. Even in drought when grit-filled west winds seared every surviving plant, there were, we were told, no excuses for leaving all the vases empty. There were always tips from the sugar gums and other trees and bushes that could be used. Boys, excluded from flower arranging, were told they shared responsibility for bringing them to school. My brother and I never brought one flower or gum tip. 
The pictures on the walls were landscape prints behind glass. A teacher working at the blackboard could glance up and see the reflection of her class. Without turning, Mrs Foley would say, 'Neil Nelson, stop poking Norman Baldwin with your ruler'. It seemed a demonstration of the mysterious powers of teachers to know when a rule was broken, or even under threat.

One picture was different from all the pleasant prints. It was what appeared to be a photograph in a wooden frame, but may have been a copy of a detailed drawing. It had hung next to a classroom doorway, and was then shifted to the corridor near the entrance to the headmaster's office. It was of a young Aboriginal woman standing with a skin cloak pulled around her shoulders. She was, the label said, Jerrybung, Queen of the Boort and Loddon Tribes. She remained in the primary school after I shifted into the extension that housed Boort Higher Elementary School. I remember no other picture of an individual, not even of King George VI. Not of General Charles Gordon of Khartoum, hero of Empire, killed in 1884. The local government district, the Gordon Shire, with its meeting place in Boort, was created the next year, and Boort had a Gordon Street, and one of the school 'houses' was Gordon. But in my eleven years at that weatherboard school sited just under the crest of Boort Hill, I do not recall one teacher referring to that unique picture, or Queen Jerrybung, or her tribe, the Djadjawurung.

The Aborigines were not absent from our classes. In many years we drew and labelled 'mia mias', spears and boomerangs. Children were asked to bring along spear points and grindstones found in paddocks when ploughs turned the distinctive black soil of what were always known as 'blackfella's ovens'. And we all knew that 'boort' was the Aboriginal word for 'smoke', or that 'boort boort' meant 'big smoke', because Aborigines, it was said, sent smoke signals from the highest point of the Hill, up where the concrete water tower gave the town supply its pressure. Living in an area littered with Aboriginal words from Barraport to Wychitella and Borung - I knew the meaning of no other Djadjawurung word.

The Victorian Readers that went from the First to the Eighth Book contained many stories of Aborigines. In the Fourth Book we read what were said to be legends 'told by the blacks to their piccaninnies': 'Why the Crow is Black', 'How the Sun was Made', 'The Magpie and the Children' and 'How Mussels Were Brought to the Creek'. The notes included in the Readers confirmed the attitudes of those times. We were asked to notice the repetition of words and told that 'Children and savages are fond of this'. We were asked why 'our native blacks are dying out'; but we were also told about the different seeds that 'blacks used for grinding', asked if we knew what yams were, and instructed that many 'savage tribes' had an animal 'totem' and it was 'held sacred'. 
The Readers' stories of Aborigines in meetings with whites included extracts from Aeneas Gunn, and we were assured that Bett-Bett, the central character in The Little Black Princess, had now grown up and become Mrs Bronson. In the story A New Years' Day Adventure in Australia, a lost drover's son was saved by two Aborigines who 'were very kind', and the drovers 'treated the two blackfellows well' giving them 'damper, tobacco and meat, and a whole bullock besides'. In the questions we were asked to think of other 'instances of kindness on the part of the blacks'. One incident described in the Fifth Book stayed with me. It was set on the Loddon River which made its slow wandering way to the Murray east of Boort, and the author mentioned the Four Post which I wrongly assumed was the Four Post that we passed on the way to Bendigo. In fact Samuel Carter's boyhood reminiscence was about events between the upper Loddon and Wimmera Rivers, 150 kilometres from Boort. Carter wrote of being attacked by Aborigines and, while no one was killed in that incident, it was apparent that violence and intimidation between blacks and whites on the squatter frontier were common. But I knew no stories of any Aborigines in the Boort area doing anything, and certainly nothing of any being killed. The map that retained so many Aboriginal names was not interspersed with Ambush Creeks, Skull Lagoons or Murdering Swamps.

We had one chance when we might have looked seriously at Aboriginal history. In our final year at Boort Higher Elementary School, in fourth form, we sat for the Intermediate examination in the local hall under the watch of the local Methodist minister. One subject was Australian history. Our main text was R.M. Crawford's Ourselves and the Pacific, first published in 1941, an imaginative and pioneering text that located Australia in the Pacific. But Crawford gave but one index entry and one short paragraph in the text to the Aborigines. The sections on the inland exploration and the advance of the squatters had almost no mention of the Aborigines. Unlike nearly all the other fifteen and sixteen-year-old students in my Intermediate year, I was a student of two books: I had inherited my brother's copy of Ernest Scott's A Short History of Australia, revised in 1947. While Scott was brief, he concluded: 'The worst features of the fading out of the native race arose from sheer brutality and treacherous murder by white settlers and their convict servants'. The process, he said, was 'grim and hateful'. No books then available to students in country schools said more, and none was as blunt.

So although we had no texts with any details about Aborigines in the present or the past, in all but our last years at school we had learnt something of them, and we had read extracts from many of those who had written about them: Gunn, Henry Kendall, Charles Bean, Mary Gilmore, Katie Langloh Parker. We had learnt the standard prejudices of the time about savages, child races, and people destined to fade away; but we had also looked at illustrations of nardoo plants 
and grindstones, read stories of Aborigines behaving admirably, and a few of us had had access to Scott's judgement that some settlers were guilty of 'the lowest depth of mean homicide'. Our education in Aboriginal history was not - as is often said - absent, but deficient. The gaps were largely because by the 1940s and 1950s so few scholars had done the research to establish the depth in time, cultural complexity and diversity of experience within Aboriginal Australia. For me, sitting at my desk in school 1796, the Aborigines always seemed to exist in distant times or places. There was no connection with any events that had happened in the landscape that we looked at, played and worked in, and travelled across. There was no connection with the lonely Jerrybung in her skin cloak.

The picture of Jerrybung dated from either 1856 when John Kerr, the magistrate at Fernihurst, drew her, or from 1863 when a photographer preserved images of the Aborigines camped on Lake Boort. I saw Jerrybung as she had been about eighty years earlier. I was one lifetime from the woman in the picture. My father and grandmother had both gone to the Boort Primary School. Even if Jerrybung had died immediately after her image had been preserved, she was in Boort within twenty-five years of my grandmother. Both my father and grandmother must have known people who had known Jerrybung. My great-grandmother, Granny McRae, was alive and well when I started school; my brother and I left our horse under the pepper trees in her backyard. Granny McRae might even have known Jerrybung, or some of the other Aborigines photographed in 1863. That closeness, to what I thought of as my place, of another people and culture, of particular people such as Jerrybung, never occurred to me in the 1940s, and can still surprise me.

Through my years at school in Boort I thought that I knew no Aborigines. It was not, I believed, until I was about sixteen and travelled outside the Boort area and saw the people who lived in the river camps near Swan Hill and Echuca that I encountered people who were obviously Aboriginal. It is only in recent years that I realised that one family living close to the school was almost certainly part-Aboriginal. The husband, George, was always called 'Darkie'. Even that gave me no clue. George was well known as he had been a talented sportsman, having played for the Boort football team as a teenager in the 1930s. But he injured his knee when there was no corrective operation, just the hope offered by bandages and quacks. Local men drove him all over the state hoping that one of the blokes said to be good with knees would get him back on the field. They failed, of course, and as George had played in a team with three other men who went on to play in Melbourne, there were stories that George would have worn the 'Big V' (represented Victoria).

I had my own reason to admire George. In about 1948 Boort was playing football against its bitter rivals, Wedderburn. Fights had broken out on the ground, the two captains were slugging it out at centre half-back, and among the sparse 
spectators on the far side of the oval close to where I was operating the score board, Charlie, a Boort man well known to me, was fighting a thug from the 'burn. Both landed thudding blows, and the thug was being urged on by three or four of his drunken mates. Moving quickly up behind Charlie, George waited. Suddenly the thug saw George, dropped his hands, and said, 'I'm not fighting with you, Darkie. I'm not fighting with you'. He turned quickly, and he and his mates hurried off. To a ten-year-old it was amazing; the humiliation of enemies by reputation. I could not wait to tell everyone.

George's son 'Saddles' was an older boy at school with me. I do not remember anyone suggesting that 'Sads' had any Aboriginal inheritance. If we had been conscious of it, we certainly would have commented in our casual, unthinking racism. No one did. While I was in primary school George and his family left the district, and passed out of local knowledge. But there is, then, just the chance that I was in primary school with someone who was part-Djadjawurung, even a relative of Jerrybung. Those people apparently so distant may have been known to Granny McRae, may have continued to live as a result of the mixing races on the frontier, and their descendants, just three or four generations on, may have been with me at school.

At Melbourne University I did not study Australian history until 1958 when I was in my third year. I was well taught. Jack La Nauze, Bob Gollan, Geoff Serle, Barry Smith and Don Baker were then in the Melbourne History Department and strangely all later went to The Australian National University. The main text books were Gordon Greenwood's edited essays by six historians, Australia: A Social and Political History, 1955, and Manning Clark's two volumes of Select Documents in Australian History, 1955. Neither lectures nor books said much about Aborigines. Greenwood and Clark have more on Chinese than Aborigines. But some historians were then aware of the absence. In 1959 La Nauze wrote: 'The Australian aboriginal is noticed in our history only as melancholy anthropological footnote'.

I had completed my last class as a student of Australian history just as John Mulvaney was starting a new scholarly interest in Aboriginal history. He surveyed the literature and the little archaeological work that had been done and, in 1962, as a result of his own work at the Kenniff Cave site in Queensland, he said that Aborigines had been in Australia for more than 13,000 years. He had begun the collection of evidence to establish that the Aborigines had a history of 30,000,40,000,60,000 ... years, so important to their own self-perception and claims to possession of Australia. But it was not until the 1970s that much new work began to be published on black and white relations on frontier settlement.

In 1963 I had to choose a topic for Master of Education thesis. I decided to write on the early attempts to 'civilise' the Aborigines of Victoria - then the Port 
Phillip District. I cannot now be sure why I chose to write on what was still an unfashionable topic, and when I did not know just what evidence was available to allow me to describe and comment on what had happened between 100 and 130 years earlier. But it was certainly true that I still wondered about the people who lived and died on the paddocks, swamps, creeks and wind-blown hills of those northern rivers and the Mallee fringe that I knew so well. And I retained the image of the lonely Jerrybung who had no history.

In 1964, in the basement of the State Library of Victoria, I read my way through seventeen boxes of reports and letters in which Port Phillip District colonial administrators had set out their dealings with Aborigines. In breaks between teaching at the Royal Melbourne Institute of Technology, I went down the curved iron stairs into the library basement, and there a man wearing a grey dust jacket showed me to an old table and chair where I worked. When I first took the papers from their boxes I was delighted to find that they were still tied in red tape. 'Government red tape' was not so much a metaphor but an extension of a reality. In those files I read the reports of the earnest Edward Parker, born in London in 1802, apprentice printer, candidate for the Methodist ministry and school teacher. From 1839 he was Assistant Protector of the Aborigines in the Loddon district. After travelling widely, Parker set up his station near Mt Franklin. It was named 'Jim Crow', but probably before 'Jim Crow' became the disparaging term for a Black American song and dance man and before it was extended to imply segregation.

In his travels in the Loddon Valley, Parker encountered cases of Aborigines being killed by settlers. In one incident an Aborigine known to Parker realised that he was about to be shot and grabbed his attacker around his legs. He was shot in the shoulder while pleading for mercy. As Aboriginal evidence was not accepted by the courts and whites would not incriminate each other, Parker soon knew there was 'no chance of justice being obtained for these unfortunate people'.

Parker learnt the Djadjawurung language (he called it Jajorurong), and made notes about beliefs and practices. But his attempts to civilise the Djadjawurung came to little and as a result of sickness, dislocation, despair and violence, the Djadjawurung were rapidly disappearing. By the early 1850s there were only about 150 of them. After Parker resigned in 1850, the station lingered on for a few years. Parker said that his failure to educate the Djadjawurung children was 'one of the most painful of the many painful remembrances of my official career'.

The bundles of red-taped papers had taught me something of Djadjawurung, but Parker had been in the south of their lands, about 150 kilometres from Boort, and close to where Carter had set his reminiscences. Parker recorded no names and no stories of the people who were photographed in their camp on Lake Boort in 1863. As Parker was the main source of information for the 
nearly all later writers on the Djadjawurung, it was obviously going to be difficult to find out more about the lower Loddon. All that I picked up were incidental scraps left by the first of the white settlers in the area: Aborigines worked for squatters around the homesteads and out on the runs by washing sheep and mustering; Frederic Godfrey, one of the brothers who took up Boort Station, employed 'Jackie Logan' as a groom and Jackie travelled all the way to Melbourne with Godfrey and his horses; there were no accounts of violence as the runs were taken up and sheep and cattle ate the grass that had once fed the game consumed by the Aborigines; but there was one story from 1849 of a Boort Aborigine being killed by a marauding group of traditional enemies from the Murray, and of warriors from Boort leaving to take revenge. Amid dispossession and imposed revolution, old enmities survived.

By a strange irony my thesis on the attempts to educate the blacks of Victoria was typed by a black woman. In 1966, with a draft of my thesis in my luggage, I went to Port Moresby to teach at the Administrative College of Papua New Guinea. Jessie, the secretary at the Admin College at Six Mile, typed the final copy for the examiners, pausing now and again to talk to students in any of the several languages that she casually commanded.

Preparing courses on new topics at the Admin College and the University of Papua New Guinea, and absorbing and being absorbed into a frontier Australian town transforming itself into a sprawling city and a capital of a foreign country, I rarely had time to think about Aborigines. I prepared nothing from the thesis for publication.

When I returned to Australia I sometimes thought about returning to the history of the people who had once owned the land that was now being worked by the fourth and fifth generation of my own family. But some other task always seemed to be close to, or just past, its deadline, and my experience in Papua New Guinea among peoples who were numerous, and retained their lands, their languages and the stories of their own past made me reluctant to write about Djadjawurung from fragments written by outsiders.

In Papua New Guinea I had walked with people on their own lands, and each rock, river bend, old garden site and sago swamp provoked its own story. At a red cliff they said this was where Wada made the commitment. One tribe had long been dominant, and the lesser and surrounding tribes were trying to put together an alliance to challenge it. But that was difficult and dangerous. If the dominant tribe learnt that another tribe was trying to bind others to an alliance it would be attacked immediately; and any minor tribe could curry favour by denouncing the new alliance to the dominant tribe. All the minor tribes were cautious when they met. And it was then that Wada called for a boy of the dominant tribe. Wada took the boy, spoke to him kindly, turned the 
boy's head away and split it with an axe, killing him instantly. All knew that the dominant tribe would learn what had happened and who was present, and take terrible revenge. Now all the minor tribes were committed, and would have to act quickly. They did, and that was how the dominant tribe was defeated and new alliances were formed.

At a clump of flowers and bright-leafed plants that stood out against a wall of rainforest, people said that was where an angry husband waited and killed his wife's young lover. It was the wife who had made the garden, and the plants kept reseeding. At a rock they showed me the teeth marks of the giant who had once roamed the area and eaten the slow and careless. Over there, they said, was the site of the village before the big flood swept through the valley; here were sago palms first planted by people now driven from the area; and that woman sitting outside her house was the descendant of the one of the few to survive from the tribes who had previously owned these lands.

To walk across the paddocks in Boort is to move within a known farming history. In the 1944 drought the dry grass was blown against that fence, drift sand piled against the barrier of grass, the fence was buried and the sheep just walked over the top; over there we felled the oak trees and the grain was so straight we split fence droppers from them; those laser-graded lucerne bays looking like lush billiard table tops were once lignum swamps; that bit of rusted iron now used to mend a sagging gate once fitted a bullock yoke; and over there Dad had yarded the draught horses and fed them before dawn so they could work all day. But just a hundred years before I was born that same country had other markers evoking other peoples' histories. Wars, ambushes, defeats, victories, escapes, acts of courage, births, jokes, love, times of hunger and plenty, marriages, quarrels, alliances were all evoked by old camp sites, creek beds, stands of timber, open spaces, sand hills and even by what was transient - the smell of bush honey and the chilling sound of a curlew in the night. What could be learnt in much of Papua New Guinea with all its frustrating complexity of different perspectives and the joining of the remembered and the mythical left me reluctant to try to write a history from loose generalizations and with almost no names of particular people and without memories that mattered to them.

Queen Jerrybung's picture continued to hang on the wall near the headmaster's office long after I had left the area. I wonder if any later teachers tried to explain who she was to children who had just travelled across ground that had meant so much to her. Then a new headmaster in a general clearing away of the old tossed her out. Fortunately there were other copies of the picture of Jerrybung, and her name and image survive. But that is about all of her that survives from the past so close. I regret that I have not tried to give her a history, but that is partly because I know it would be so much less than I would want and she deserves.

My thanks to Paul Haw and John Nelson who aided my recall. 
This text taken from The Boy from Boort: Remembering Hank Nelson, Edited by Bill Gammage, Brij V. Lal, Gavan Daws, published 2014 by ANU Press, The Australian National University, Canberra, Australia. 